\title{
Biochemical markers of psoriasis as a metabolic disease
}

\author{
Agnieszka Gerkowicz ${ }^{1}$, Aldona Pietrzak ${ }^{1}$, Jacek Cezary Szepietowski ${ }^{2}$, \\ Sebastian Radej ${ }^{3}$, Grażyna Chodorowska ${ }^{1}$
}

\author{
${ }^{1}$ Department of Dermatology, Venereology and Pediatric Dermatology, \\ Medical University of Lublin, Poland \\ ${ }^{2}$ Department of Dermatology, Venereology and Allergology, Medical University, Wroclaw, Poland \\ ${ }^{3}$ Department of Human Anatomy Medical University of Lublin, Poland
}

\begin{abstract}
Psoriasis is a chronic immune mediated inflammatory skin disease with a population prevalence of $2-3 \%$. In recent years, psoriasis has been recognized as a systemic disease associated with metabolic syndrome or its components such as: obesity, insulin resistance, hypertension and atherogenic dyslipidemia. Many bioactive substances have appeared to be related to metabolic syndrome. Based on current literature, we here discuss the possible role of adiponectin, leptin, ghrelin, resistin, inflammatory cytokines, plasminogen activator inhibitor 1, uric acid, C-reactive protein and lipid abnormalities in psoriasis and in metabolic syndrome. (Folia Histochemica et Cytobiologica 2012, Vol. 50, No. 2, 155-170)
\end{abstract}

Key words: psoriasis, metabolic syndrome, adipokines, cytokines, uric acid, CRP, PAI-1

\section{Introduction}

Psoriasis is an immune mediated inflammatory skin disease characterized by epidermal hyperproliferation, impaired differentiation of keratinocytes, excessive angiogenesis and immunological dysfunction [1-3]. The immunologic cells engaged in the pathogenesis of psoriasis which have been the focus of attention in recent years include not only lymphocytes Th1, but also Th17, Th22 and regulatory T lymphocytes (Treg). Equally important immunological cells are Langerhans cells and dermal dendritic cells (dDC) (Figure 1). One of the immunological disturbances is the predominance of Th1 response [4-6]. An elevated level of IFN- $\gamma$, together with decreased levels of IL-4, fosters the inhibition of Th2 immune response $[4,6]$. The leading role in the regulation of immune

Correspondence address: A. Gerkowicz, Department of Dermatology, Venereology and Pediatric Dermatology, Medical University of Lublin, Radziwillowska Str. 13, 20-080 Lublin, Poland; e-mail: agerkowicz@wp.pl response in psoriasis is attributed to dendritic cells (DC). A significant increase in the number of dendritic cells which secrete IL-20, IL-23 and TNF-alpha has been observed in patients with psoriasis [7-9]. Activated DC secrete, among others, IL-12, inducing Th-1 immune response and IL-23, which favors the differentiation of naive lymphocytes into Th17 cells [10-12]. Naive T lymphocytes differentiation into Th17 cells depends on the presence of IL- $1 \beta$, IL-6, IL-21, TGF- $\beta$ and IL-23 [13, 14]. An increased percentage of Th17 lymphocytes and its cytokines (IL-17a, IL-6) has also been observed in psoriasis [15-21]. Studies conducted by Harper et al. [21] and Norgales et al. [22] revealed the presence of Th 22 lymphocytes in the skin of patients with psoriasis. Differentiation of the Th 22 lymphocytes which produce IL-22 is induced by the presence of IL-6, TNF-alpha, plasmacytoid dendritic cells and Langerhans cells [23-25]. In response to IL-17 and IL-22 stimulation, keratinocytes increase the secretion of IL-8. Furthermore, INF- $\gamma$ (synthesized by Th1 cells and dendritic cells) together with IL-22, IL-6 and IL-20, enhances the proliferation of keratinocytes [18, 26, 27]. Acti- 


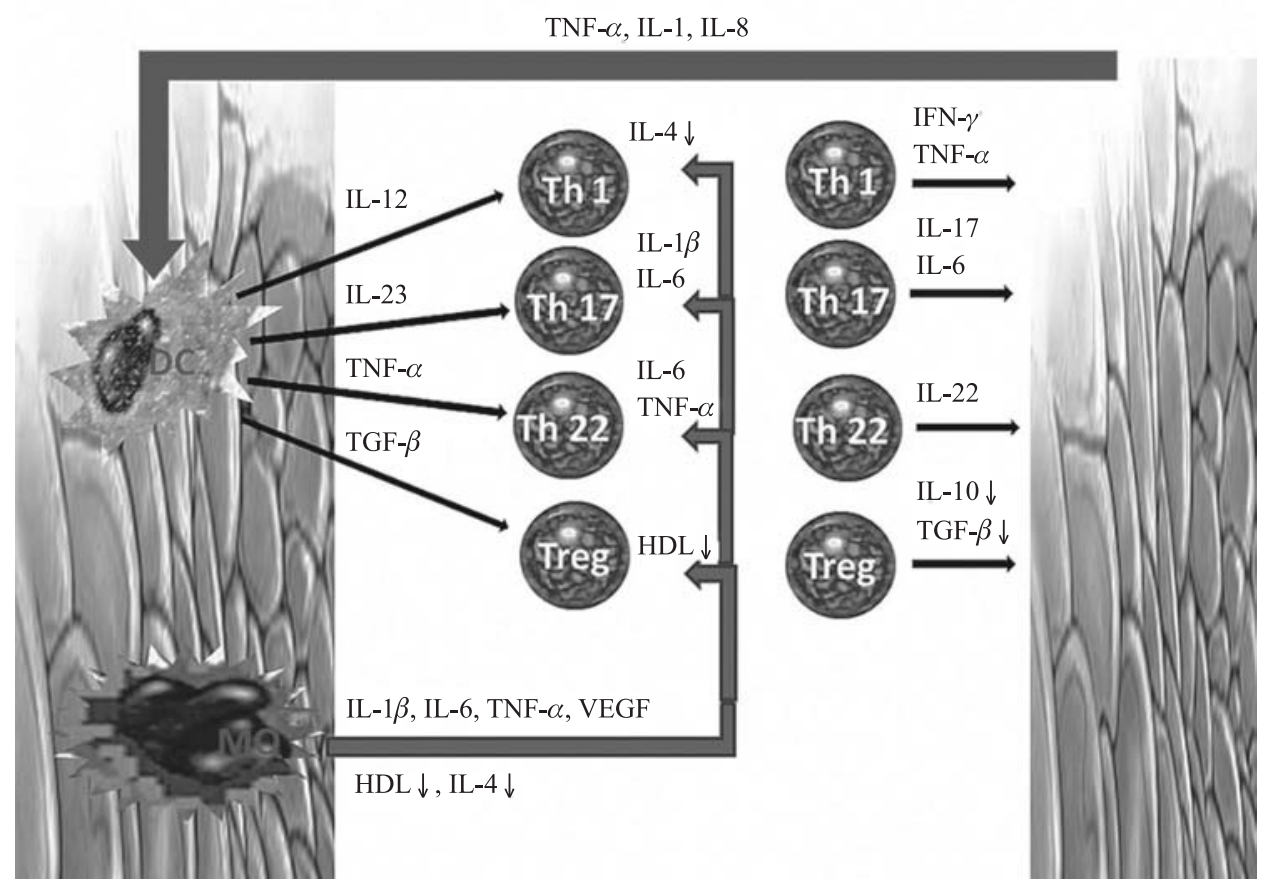

Figure 1. DC - dendritic cells; MQ — macrophages, T — lymphocytes subpopulations (Th1, Th17, Th22, Treg); HDL — high density lipoproteins cholesterol; INF- $\gamma$ - interferon gamma; TGFâ — transforming growth factor beta; VEGF — vascular endothelial growth factor; TNF- $\alpha$ - tumor necrosis factor alpha and interleukins which are involved in the pathogenesis of psoriasis

vated keratinocytes secrete increased amounts of TNF-alpha, IL-1 and IL-8, enhancing inflammation and activation of dendritic cells. The key role in the inhibition of inflammatory reaction and induction of tolerance to antigen play Treg lymphocytes. Decreased levels of Treg lymphocytes have been demonstrated in Graft-Versus-Host Disease as well as in breast, colon and lung cancer [28-33]. A decreased percentage or impaired function of Treg lymphocytes, observed also in psoriasis, may lead to an increased secretion of proinflammatory cytokines, which subsequently results in enhanced proliferation of keratinocytes [34, 35]. Disturbances in other tissues may occur as a result of dysfunction and changed percentage of Treg and Th1 lymphocytes. Cheng et al. [36] reported that a decreased percentage of Treg lymphocytes and an increased percentage of Th 17 cells in patients with acute coronary syndrome may be one of the potential causes of destabilization of atherosclerotic plaques.

It is estimated that psoriasis affects $120-180$ million people worldwide [37]. A growing number of new cases of psoriasis are reported $[37,38]$. Recently, psoriasis has been recognized as a systemic disease associated with multiple comorbidities $[1,3]$. The lipid disturbances in the course of psoriasis have been analyzed since 1924 [39, 40]. Researchers have focused their attention on comorbidities in psoriasis including: type 2 diabetes, ath- erosclerosis, hypertension, myocardial infarction, depression and obesity. Hyperuricemia in patients with psoriasis has been noted [1, 3, 41-45]. It seems that metabolic syndrome, for which the coexistence of well-known cardiovascular disease risk factors is characteristic, may be the connection between cardiovascular complications and type 2 diabetes in patients with psoriasis [1].

The first description of a possible coexistence of metabolic disturbances and cardiovascular risk factors was made at the beginning of the $20^{\text {th }}$ century [46]. It was not until the end of that century when the definition and criteria of metabolic syndrome were introduced, being later modified [46].

Guidelines proposed by the International Diabetes Federation (IDF) are the most up-to-date criteria for diagnosing metabolic syndrome [47]. According to the new IDF definition, for a person to be defined as having metabolic syndrome they must have:

1. Central obesity, defined as a waist circumference (of which the values are ethnicity-specific), plus any two of the following factors:

a. Raised triglycerides $\geq 150 \mathrm{mg} / \mathrm{dL}(1.7 \mathrm{mmol} / \mathrm{L})$ or specific treatment for this lipid abnormality,

b. Reduced HDL cholesterol: $<40 \mathrm{mg} / \mathrm{dL}(1.03$ $\mathrm{mmol} / \mathrm{L})$ in males, $<50 \mathrm{mg} / \mathrm{dL}(1.29 \mathrm{mmol} / \mathrm{L})$ in females, or specific treatment for this lipid abnormality, 
c. Raised blood pressure (BP): systolic BP $\geq 130$ or diastolic $\mathrm{BP} \geq 85 \mathrm{~mm} \mathrm{Hg}$, or treatment for previously diagnosed hypertension,

d. Raised fasting plasma glucose $\geq 100 \mathrm{mg} / \mathrm{dL}$ $(5.6 \mathrm{mmol} / \mathrm{L})$ or previously diagnosed type 2 diabetes.

Comorbidity of metabolic syndrome and psoriasis has been stressed by many researchers. However, the prevalence of metabolic syndrome among patients with psoriasis varies according to the study and the adopted criteria of metabolic syndrome. Sommer et al. [45] reported that metabolic syndrome in patients with psoriasis was at least twice as common as in a control group. The results of this study are consistent with data published by Love et al. [48]. However, in both studies, different criteria of metabolic syndrome were used [45, 48]. Love et al. [48] found the prevalence of metabolic syndrome to be $40 \%$ among adult patients with psoriasis and $23 \%$ in a control group. In another study performed on 338 patients with plaque psoriasis and 334 patients with other skin diseases, a higher prevalence of metabolic syndrome was observed in the first group $(30.1 \%$ and $20.6 \%$ respectively). Moreover, the prevalence of metabolic syndrome correlated with the duration of psoriasis [44]. Similar results were obtained by Nisa et al. [49] who observed metabolic syndrome in $28 \%$ of patients with psoriasis. Mebazaa et al. [50] also observed a higher prevalence of metabolic syndrome in patients with psoriasis than in a control group, although it was not statistically significant. It is worth noting that metabolic syndrome has also been observed in patients with psoriatic arthritis. Raychaudhuri et al. [51] showed that as many as $58 \%$ of men and $60 \%$ of women with psoriatic arthritis fulfilled the criteria of metabolic syndrome. Additionally, the association between single features of metabolic syndrome and psoriasis has also been investigated [43, 52].

The exact mechanism for the development of metabolic syndrome in patients with psoriasis is yet to be fully understood. Some researchers have suggested that psoriasis predisposes to the development of obesity or hypertension due to a stressful life, reduced physical activity, or greater tobacco and/or alcohol consumption [41].

Currently, it is considered that insulin resistance and abdominal obesity play vital roles in the pathogenesis of metabolic syndrome [46, 47]. The possible comorbidity of psoriasis and obesity has been suggested by many authors. It has been reported that obesity is more common in patients with psoriasis $[53,54]$. Naldi et al. [55] demonstrated that the risk of developing psoriasis is related to BMI (body mass index), whereas the risk is higher in obese people.
Nowadays, white fat tissue is considered to be an active endocrine organ which has an effect on many metabolic processes. Fat tissue cells (adipocytes) can produce and secrete numerous bioactive elements known as adipokines including many cytokines, hormones and growth factors $[56,57]$. They are involved in preserving homeostasis, regulating the glucose and lipid metabolism and blood pressure. Adipokines also take part in regulating the sensitivity to insulin and they are involved in inflammatory and immune processes [57]. Therefore, taking numerous functions into consideration, adipokines are under constant scrutiny. The contribution of adipokines to metabolic syndrome has also been reported [58].

The IDF has suggested using a so called 'platinum standard' in research studies related to metabolic syndrome which includes additional metabolic criteria such as: leptin, adiponectin, apolipoprotein B (Apo B), low density lipoprotein (LDL), proinflammatory cytokines and C-reactive protein (CRP) levels as well as markers of prothrombotic state [47].

The aim of this study is to review current literature data concerning the biochemical markers of metabolic syndrome in patients with psoriasis.

\section{Adiponectin}

Adiponectin is a polypeptide composed of 244 amino acids. It is synthesized mostly by adipocytes [59]. It has been proved that the gene which codes adiponectin (AMP1) is localized on chromosome 3q27. Moreover, it has been found that the locus of proneness to type 2 diabetes is localized on the same chromosome [60]. Adiponectin can occur as an oligomeric complex as well as a high molecular weight adiponectin - HMV which is its most active form [61].

It is recognized that adiponectin has anti-inflammatory properties: it negatively regulates synthesis of TNF-alpha in fat tissue, and inhibits secretion of this cytokine by heart muscle cells. Additionally, adiponectin inhibits production of IL-8, vascular adhesion molecule-1 (VCAM-1), and reactive oxygen species (ROS) in endothelial cells. It also stimulates synthesis of IL-10 [59, 62].

This protein has also a protective antiatherogenic effect which arises through decreasing monocyte adhesion to the endothelium and reducing synthesis of VCAM-1, intercellular adhesion molecule-1 (ICAM-1) and E-selectin [59, 63]. Adiponectin increases the synthesis of nitric oxide in endothelial cells by intensifying the synthesis of mRNA for endothelial nitric oxide synthase (eNOS), subsequently relaxing smooth muscles [59, 63]. In vitro studies on cell cultures show 
that adiponectin has an anti-apoptotic effect on heart muscle cells and fibroblasts [64]. Therefore, some authors recommend regarding its decreased blood concentration as a risk factor for cardiovascular disease [65].

It is worth noting that low plasma or serum levels of adiponectin have been found in obesity, type 2 diabetes, coronary disease, hypertension and non-alcoholic fatty liver disease in obese patients [59, 66, 67]. It is interesting that in other inflammatory diseases such as lupus erythematosus, cystic fibrosis and type 1 diabetes, circulating levels of adiponectin are elevated [68]. These observations may suggest that adiponectin levels are under the control of other regulatory mechanisms in chronic inflammatory diseases related to obesity [63].

Considering the fact that adiponectin is related to metabolic syndrome [62], which can coexist with psoriasis, it cannot be excluded that this protein plays a role in pathophysiological processes in psoriasis.

Several studies have reported decreased circulating levels of adiponectin in patients with psoriasis compared to a control group [69, 70]. Additionally, researchers have determined that adiponectin concentration levels are negatively correlated with psoriasis severity measured by PASI (Psoriasis Area and Severity Index) as well as with the plasma concentration of TNF-alpha [69]. Shibata et al. [71] demonstrated a significant increase of serum adiponectin concentration in patients with psoriasis and psoriatic arthritis who were treated either with anti-TNF-alpha agents or with narrowband UVB. Moreover, they showed that an increase of adiponectin concentration was associated with a decrease of IL- 6 concentration.

Kaur et al. [72] investigated the correlation between adiponectin, body weight and oxidative stress. Obese patients with psoriasis had a significantly higher concentration of IL-6, which additionally was negatively correlated with adiponectin concentration. Only in obese psoriatic patients was the glutathione redox ratio (GHS), which is a marker of oxidative stress, significantly higher, and it correlated negatively with the concentration of adiponectin.

It seems that obesity in psoriatic patients could be connected to decreased protective influence of adiponectin and with enhanced systemic inflammatory process and oxidative stress [72]. Coimbra et al. [73] achieved similar results. They found that the concentration of circulating adiponectin was significantly lower in psoriatic patients with BMI $>30$ compared to psoriatic patients with $\mathrm{BMI}<25$ and to a control group.

The results of this study may point to a correlation between psoriasis and obesity, and its plausible influence on lowering adiponectin concentration, which correlated negatively with BMI [73].

\section{Leptin}

Leptin is a polypeptide composed of 166 amino acids of molecular mass $14 \mathrm{kDa}$. It is coded by obesity gene localized on the 7q31 chromosome. [57, 63, 74, 75]. Most of this protein is synthesized in adipocytes, though some minor quantities are found in placenta, ovaries, skeletal muscles, stomach, liver and pituitary gland $[60,72]$.

The main role of leptin is to regulate food consumption through a neuroendocrine system by reducing appetite [57, 76]. It has also an effect on immunological processes. Moreover, it is involved in wound healing and hair growth [76, 77].

Interestingly, people with leptin deficiency are very obese [63]. On the other hand, obese patients have higher leptin concentration. However, they do not react to higher leptin levels by a decrease in their appetite [76]. Therefore, it is supposed that obese patients are resistant to leptin, just as in type 2 diabetes, where insulin resistance is observed [63, 76, 78]. Furthermore, hyperleptinemia caused by obesity is an important risk factor leading to the development of type 2 diabetes [79].

Hyperleptinemia may lead to the development of atherosclerosis in obese patients [80]. Other authors suggest that leptin is involved in the formation of atheromatous plaques [81]. The suggestion has been made to regard elevated leptin levels as an independent factor indicating future coronary disease and cardiovascular complications [82].

An assumption, based on the articles mentioned above, can be made that leptin is correlated with metabolic syndrome, and moreover it may be involved in the pathophysiology of psoriasis. Wang et al. [74] found higher serum leptin levels in women and men with psoriasis compared to a control group. Higher plasma leptin levels in patients with psoriasis were also noted in a Japanese population [69]. Furthermore, higher leptin concentration was associated with higher PASI, although it was not statistically significant [69]. In another study, significantly elevated serum leptin concentration was found in female patients with psoriasis, whereas male patients with psoriasis showed a trend towards higher values compared to the control groups of the same gender. Furthermore, patients with BMI > $>30$ had significantly higher leptin concentration than the groups with lower BMI, as well as the control group. However, it is worth noting that as many as $58 \%$ of patients with the highest BMI were women [73]. A study conducted by Johnston et al. [83] on 30 obese patients with plaque psoriasis and a control group (BMI 30.5, 30.8 respectively) did 
not prove any statistically important differences in the serum levels of leptin and its soluble receptors compared to the control group. However, the authors proved that there was a significant correlation between BMI, waist circumference and leptin concentration [83]. Therefore, it seems that leptin concentration is related to BMI, and so hyperleptinemia in patients with psoriasis may be correlated with obesity [73].

It has been proposed that leptin, through promoting synthesis of Th1 cytokines and inhibiting synthesis of Th2, might be involved in the pathogenesis of psoriasis [73, 74]. Considering that inflammation mediated by Th1 lymphocytes is one of the factors leading to the development of atherosclerosis and coronary disease [84], it seems that leptin may be a connection between psoriasis and cardiovascular complications [85].

\section{Resistin}

Resistin is a polypeptide composed of 108 amino acids of molecular weight $12.5 \mathrm{kDa}$ [86]. High cystein content is a characteristic feature of resistin [57]. This adipokine is synthesized mostly by macrophages and monocytes contained in fat tissue [83, 87, 88]. Additionally, resistin is produced in bone marrow, placenta, pancreas, joint fluid, synovial tissue and the peripheral blood [89-92].

There have been suggestions that resistin plays a role in inflammation. It has been proved that proinflammatory cytokines such as TNF-alpha, IL-6, IL-1beta and lipopolysaccharides are able to increase the expression of resistin in peripheral blood mononuclear cells (PBMCs); however, resistin itself is capable of inducing the synthesis of TNF-alpha or IL-12 [63, 93, 94].

It is worth noting that resistin owes its name to the observed influence of this protein on insulin resistance [95]. However, resistin's role in obesity and insulin resistance is not yet fully understood [96]. Mice which were given resistin had a lowered sensitivity to insulin. Another study has reported higher resistin levels in obese mice [97, 98].

Different results were described in a study in which resistin concentration was measured and compared in obese patients, obese patients with type 2 diabetes, and patients with normal body weight. A negative correlation was found between the concentration of resistin and sensitivity to insulin only in the patients with normal body weight [99]. Another study revealed that synthesis of resistin by fat tissue in morbidly obese patients was significantly higher compared to slim people; however, no correlation with BMI was found [100].
Different results observed in humans and mice might suggest that resistin in the human body is synthesized mostly by non-adipose components of fat tissue, which would explain the observed phenomenon [86].

A link between resistin and cardiovascular complications has been emphasized [86]. Significantly elevated serum resistin levels in patients with type 2 diabetes during acute STEMI (acute ST segment elevation myocardial infarction) has been described compared to patients with acute STEMI but without type 2 diabetes, or to a control group [101]. This suggests that resistin may be involved in the pathogenesis of metabolic syndrome.

Elevated resistin levels have been found in patients with psoriasis, and moreover its concentration corresponded with PASI index [73, 83, 85]. It is recognized that obesity is associated with chronic inflammation, which is characterized by elevated proinflammatory cytokine synthesis. Considering this fact, and the ability of resistin to induce synthesis of pro-inflammatory cytokines, it cannot be excluded that resistin is involved in the development of metabolic syndrome observed in patients with psoriasis [73, 85, 102].

\section{Ghrelin}

Gherlin is a peptide hormone similar in structure to motilin [103]. It was discovered by Kojima et al. [103] during their search for the natural ligand of a growth hormone secretagogues-receptor (GHS-R). Ghrelin is composed of 28 amino acids. Two forms of ghrelin are distinguished: acylated and unacylated [103-105]. The main source of ghrelin is a mucous membrane of the stomach, but ghrelin is also synthesized in many other organs [106]. Secretion of ghrelin increases when energy balance is negative, which leads to increased appetite and decreased energy expenditure [106].

Recently, it has been suggested that ghrelin takes part in the development of metabolic syndrome [107]. Ghrelin concentration decreases in conditions such as obesity, type 2 diabetes and hypertension [108, 109].

We can find no studies covering the role of ghrelin in psoriasis. However, some authors have suggested that if ghrelin plays a role in the pathogenesis of obesity, which is one of the elements of metabolic syndrome, it can also take part in the pathogenesis of psoriasis [102].

\section{Interleukin-6 (IL-6)}

IL-6 is one of the most important inflammatory cytokines. It is synthesized by various cells such as: monocytes, fibroblasts, endothelial cells and adipocytes upon exposure to appropriate stimuli [63, 110]. 
Particularly interesting is the study conducted by Fujishima et al. [111]. The authors showed that IL-17F was able to induce synthesis of IL-6, both in normal human epidermal keratinocytes (NHEKs) and in mouse skin. It is worth noting that NHEKs expressed much higher amounts of IL-6 after stimulation by IL-17F than by IL-17A or TNF-alpha. The authors suggest that IL-17F may be a crucial cytokine that induces IL-6 expression in NHEKs [112]. IL-6 acts as a chemotactic factor for T cells, thus it stimulates the migration of T cells into the epidermis. IL-6 influences the growth and differentiation of dermal and epidermal cells [112] and is also involved in hematopoiesis [112].

It has been proved that the synthesis of IL- 6 in fat tissue and its circulating levels are positively correlated with obesity, inadequate glucose tolerance, and resistance to insulin [113, 114]. Moreover, a reduction of body weight is associated with reduced concentration of this interleukin, as well as reduction of its synthesis in fat tissue [114]. Esteve et al. [115] found that serum IL-6 concentration was negatively correlated with sensitivity to insulin, whereas it showed a positive correlation with BMI, blood pressure values and triglyceride levels. It was also indicated that IL-6 concentration was positively correlated with intima media thickness. Nishida et al. [116] suggested considering serum concentration of IL-6 as a marker of processes which might lead to early arterial alterations in men.

Significantly increased serum levels of IL-6 have been reported in psoriatic patients. [73]. A positive correlation between elevated IL-6 levels and PASI has also been proved [73]. It is worth noting that higher IL-6 levels and its receptor have been observed in psoriatic plaques [117].

It is thought that obesity has a negative influence on the course of psoriasis [118], due to the increased synthesis of leptin, IL-6, TNF-alpha and reduced production of adiponectin by fat tissue [73]. A negative correlation between plasma IL-6 and adiponectin levels in obese patients has been observed [72]. Kaur et al. [72] noted a statistically significant elevation of IL- 6 concentration in obese patients with psoriasis compared to a control group. In patients with psoriasis and with normal body weight, the plasma concentration of IL-6 was elevated in relation to the control group, although it was not significant. Johnston et al. [83] came to a similar conclusion. They observed elevated levels of IL-6 in obese patients with psoriasis.

Another study found a positive correlation between plasma concentration of IL- 6 and the oxidized LDL- $\beta 2$-glycoprotein complexes (oxLDL-b2-GPI) in patients with psoriasis [119]. Furthermore, a concentration of oxidized LDL and oxidized LDL- $\beta 2$-glyco- protein complexes showed a positive correlation with BMI. According to the authors, the correlation between oxLDL-b2-GPI, IL-6 and BMI may suggest a connection between LDL oxidation and inflammation, including the inflammatory process observed in obesity.

\section{Interleukin-8 (IL-8)}

IL-8 is a chemokine involved in many pathological processes. The main function of IL- 8 is a chemotaxis of neutrophils to a place affected by inflammation. It also induces antibacterial features of neutrophils. Apart from that, IL-8 induces angiogenesis and influences other cells, which take part in inflammatory response including: $T$ lymphocytes, natural killer cells (NK) and basophils, and it is also chemotactic towards keratinocytes [112, 120, 121].

Authors have drawn attention to the fact that IL-8 plays a role in the pathogenesis of type 2 diabetes and of atherosclerosis [122]. Significantly higher circulating levels of IL-8 have been found in patients with heart failure and metabolic syndrome compared to patients with heart failure without metabolic syndrome [123]. It has been proved that proinflammatory cytokines such as TNF-alpha, IL-1 and CRP induce synthesis of IL-8 in human adipocytes [124, 125]. Kobashi et al. [125] stated that IL-8 reduces phosphorylation of AKT by insulin in human adipocytes, which can induce resistance to insulin.

A significantly elevated concentration of IL- 8 has been found in patients with acute psoriasis [126]. Another study showed a higher IL-8 plasma concentration in patients with psoriasis, which decreased with the improvement of clinical appearance [127]. In a study performed on a Japanese population, a significant elevation of serum IL- 8 levels in patients with psoriasis was found, although a correlation with PASI was not observed [128]. The authors pointed out enhanced local synthesis of mRNA for IL-8 or its receptors in psoriatic plaques $[126,129]$.

To date, there have been no studies evaluating the correlation between IL-8 levels and the development of metabolic syndrome in patients with psoriasis. However, when the role of this cytokine in the pathogenesis of insulin resistance, type 2 diabetes or atherosclerosis $[122,125,130]$ is taken under consideration, it cannot be excluded that elevated circulating levels of IL-8 in patients with psoriasis may contribute to the maintenance of the inflammation, which plays a vital role in the pathogenesis of metabolic syndrome.

\section{Tumor necrosis factor-alpha (TNF-alpha)}

TNF-alpha is a proinflammatory cytokine produced by various cells such as: lymphocytes, monocytes/mac- 
rophages, mast cells and NK cells [63]. TNF-alpha influences the proliferation, activation or differentiation of many cells [131]. TNF-alpha also increases the synthesis of some proinflammatory cytokines, growth factors and adhesive molecules [112]. Several studies have shown that TNF-alpha may impair insulin signaling in many cells such as liver, adipose tissue or skeletal muscles [132-134]. This cytokine may also lead to insulin resistance through the inhibition of phosphorylation of tyrosine receptor and insulin receptor substrate 1 (IRS-1) [39]. It has been observed that obese mice did not develop insulin resistance if TNF-alpha activity had been blocked [135].

Increased levels of TNF-alpha have been reported in obese patients [136]. A positive correlation between TNF-alpha and BMI has also been reported [137]. Recently, it was reported that elevated plasma levels of TNF-alpha are associated with left ventricular diastolic dysfunction, which is one of the earliest manifestations of left ventricular dysfunction due to diabetes mellitus [138], while administration of TNF-alpha inhibitors leads to an increase of HDL levels [39]. It has been stressed that TNF-alpha is involved in the pathogenesis of metabolic syndrome $[1,46]$.

TNF-alpha is one of the major cytokines in the pathogenesis of psoriasis. Elevated levels of this cytokine have been reported in many studies in patients with active psoriasis $[112,139]$. A positive correlation between serum levels of TNF-alpha and PASI has been noted [112]. It has been shown that TNF-alpha levels negatively correlated with plasma levels of adiponectin, while this cytokine did not show any correlation with leptin levels in patients with psoriasis [69].

In contrast to other adipokines, TNF-alpha is synthesized not only within adipose tissue. Therefore, elevated levels of TNF-alpha, which are observed in the serum of patients with psoriasis, may also result from the severe inflammatory process in psoriasis as well as from the contribution of other cells in the synthesis of this cytokine [63]. It is interesting that several research studies have shown increased body weight in patients with psoriasis after therapy with anti-TNF-alpha agents [140-142].

\section{Interleukin-17 (IL-17)}

IL-17 belongs to the cytokines produced by Th 17 cells [143]. This cytokine leads to the mobilization of neutrophils [144], and stimulates secretion of IL-6, IL-8, prostaglandin E2 (PGE2) and granulocytemacrophage colony-stimulating factor, in fibroblastic, epithelial and endothelial cells [145-147]. IL-17 induces the expression of ICAM 1 on fibroblasts [146] and it enhances the maturation of dendritic cells $[147,148]$.
Recently, IL-17 has been found to take part in the pathogenesis of multiple sclerosis, inflammatory bowel diseases and rheumatoid arthritis, as well as psoriasis [144].

Elevated levels of IL-17 have been reported in obese patients [149, 150]. However, it has not been elucidated whether IL-17 influences metabolism and leads to the development of obesity, or whether the elevated synthesis of this cytokine results from inflammation observed in the course of obesity [150]. It has also been reported that $\mathrm{T}$ cells localized in adipose tissue produce IL-17 [150]. Moreover, this study showed that IL-17 regulates adipogenesis and glucose metabolism [150]. Significantly elevated serum levels of IL-17 have been observed in patients with type 2 diabetes [151].

It has also been shown that patients with acute coronary syndrome have significantly higher levels of IL-17 than patients with stable angina or non-cardiac chest pain [152]. In other studies, elevated plasma or serum levels of IL-17 were also reported in patients with non stable angina or in patients with acute myocardial infarction $[153,154]$. It has been suggested that increased levels of IL-17 may be associated with ischemic heart disease [154].

It is interesting that decreased serum levels of IL-17 were observed in patients with metabolic syndrome compared to a control group [155]. It is worth noting that a decline in IL-17 levels was associated with an increase of TGF $\beta$ levels [155]. On the other hand, the association between IL-17 and heart disease, hypertension or type 2 diabetes suggests the possible role of this cytokine in the pathogenesis of metabolic syndrome [155].

Nowadays, it is known that IL-17 plays a vital role in the pathogenesis of psoriasis [156]. Fujishima et al. [111] demonstrated that CD4 ${ }^{+}$T lymphocytes subsets secreted higher amounts of IL-17F in psoriatic lesions than in non-lesional skin. It has also been shown that IL-17F is a strong inducer of IL-6 expression in keratinocytes. Thus, it was suggested that the IL-17F/IL-6 axis might enhance inflammation in psoriatic skin [111]. A positive correlation between elevated serum levels of IL-17 and PASI has been reported [128]. Moreover, biologic agents that inhibit the function of Th 17 cells lead to a decrease of IL-17 production and to an improvement in the clinical condition of patients [157]. However, Nakajima et al. [143] reported no detectable serum levels of IL-17, either in patients with psoriasis or in a control group. So far, there have been no studies which determine the correlation between circulating levels of IL-17 and the occurrence of metabolic syndrome in patients with psoriasis.

Considering the fact that IL-17 is involved in the pathogenesis of psoriasis and atherosclerosis, it has 
been suggested that the possible link between psoriasis and one of the metabolic syndrome complications such as myocardial infarction, might be IL-17 [152].

\section{Interleukin-18 (IL-18)}

IL-18 exerts its activity on innate immunity but also on Th1 and Th2 driven immune response [158]. Together with IL-12, it triggers the synthesis of INF $\gamma$ by $\mathrm{T}$ helper and T cytotoxic and NK cells. As a result, INF $\gamma$ leads to a decreased Th2 response and an increased Th1 response [159]. IL-18 has been reported to induce the production of IL-4, IL-13 by basophils, mast cells, T cells and NK cells [158]. Moreover, IL-18 is synthesized by adipocytes and resident macrophages within adipose tissue $[160,161]$. Production of this cytokine has also been shown within atherosclerotic plaques [162]. According to some authors, IL-18 may be responsible for the instability of atherosclerotic plaques [163].

In a study of 10,600 European men, significantly increased baseline plasma levels of IL-18 were reported among patients who developed a coronary event during the study compared to those who did not [164]. It was suggested that plasma levels of IL-18 might be considered as an independent predictor of future coronary events $[164,165]$. However, Weiss et al. [160] reported that expression levels of IL-18 in adipose tissue were significantly lower in patients with cardiovascular disease compared to those without it.

An elevated concentration of serum IL-18 is associated with an increased risk of the development of type 2 diabetes, both in middle-aged men and women [166]. Hung et al. [167] demonstrated in a large population study that serum levels of IL-18 correlated with IL-6 and C-reactive protein. Moreover, the concentration of IL-18 correlated with waist circumference, triglyceride, blood pressure, and insulin levels, both in men and women. An inverse correlation was observed between IL-18 and HDL levels. According to the authors, IL-18 might be involved in the pathogenesis of metabolic syndrome. Another study reported an association between elevated plasma levels of IL-18 and higher metabolic syndrome prevalence [168].

Increased synthesis of IL-18 has also been reported in psoriasis [158]. Overproduction of IL-18 mRNA levels and IL-18 receptor mRNA was observed within skin lesions in patients with psoriasis compared to a healthy control group [169]. Increased plasma and serum levels of IL-18 were revealed in patients with psoriasis compared to a control group [170-172]. An association between concentration of IL-18 and PASI index has also been reported $[171,173]$.
To date, there have been no studies evaluating the association between IL-18 levels and metabolic syndrome prevalence in psoriasis. On the other hand, the role of IL-18, both in the pathogenesis of psoriasis and metabolic syndrome, has been reported [112, $158,167,169,174]$. Therefore, given the higher prevalence of the components of metabolic syndrome such as hyperlipidemia, hypertension and type 2 diabetes in patients with moderate to severe psoriasis, it might be suspected that IL-18 is involved in the development of metabolic syndrome in patients with psoriasis. However, this hypothesis requires further studies [45].

\section{Interleukin-23 (IL-23)}

IL-23 is synthesized by antigen presenting cells, mainly by dendritic cells [175]. It plays a vital role in the type 1 T cells immune response and furthermore it triggers cytotoxicity of lymphocytes $\mathrm{CD} 8^{+}$. IL-23 induces development of Th 17 cells which produce IL-17, IL-22 and TNF-alpha [175]. It is considered that IL-23 is a potent stimulus which leads to production of IL-17 $[176,177]$. IL-23 has been demonstrated to be a key cytokine in the inflammation in peripheral tissues [178]. Increased concentration in IL-23 has been observed in obese women [149]. Recently, it was reported that IL-23/Th17 pathway is involved in the pathogenesis of psoriasis and numerous inflammatory diseases [179].

The results of studies evaluating the levels of IL-23 in patients with psoriasis are ambiguous. Nakajima et al. [143] demonstrated undetectable serum levels of IL-23, both in patients with psoriasis and in a control group. But Coimbra et al. [127] reported significantly elevated serum levels of IL-23 in patients with psoriasis, which decreased after three weeks of PUVA or NB-UVB therapy.

Monoclonal antibodies derived against IL-12/ /IL-23 have been observed to lead to a decrease of IL-17 levels [152]. Taking into consideration the fact that inhibiting IL-17 in mice leads to a reduction of atherosclerotic plaque size, it is suggested that in humans, a reduction of IL-17 production may inhibit the development of atherosclerosis [152]. Thus it may be suspected that the IL-23/IL-17 cytokine axis is involved in the pathogenesis of cardiovascular disorders. However, precise recognition of its role needs further research.

\section{Interleukin-1 beta (IL-1 beta)}

IL-1 beta belongs to the IL-1 family. Due to its proinflammatory properties, ability to induce synthesis of 
other cytokines by T cells and to activate neutrophils, monocytes, eosinophils or basophils [112], IL-1 beta is involved in the pathogenesis of a number of autoimmune and inflammatory diseases [180].

Recently, there has been a focus on the link between IL-1 beta and metabolic disorders including metabolic syndrome [181]. Increased expression of IL-1 beta in adipose tissue of obese subjects has been reported [182]. It was revealed that patients with elevated plasma levels of IL-6 and with detectable levels of IL-1 beta had a roughly three-fold higher risk of developing type 2 diabetes than that of a control group. Patients who had only elevated levels of IL-6 and undetectable levels of IL-1 beta did not have an increased risk of type 2 diabetes compared to the control subjects [183]. The authors suggested that interaction between IL- 6 and IL-1 beta may be involved in the pathogenesis of type 2 diabetes [183].

Jager et al. [181] demonstrated that IL-1 beta inhibits insulin-induced glucose transport in adipocytes by decreasing an expression of insulin receptor substrate 1 (IRS-1). According to the authors, IL-1 beta, which is produced by adipose tissue-resident macrophages, can impair adipocytes' biology and lead to the development of insulin resistance.

An attempt has been made to evaluate the role of IL-1 beta in the pathogenesis of psoriasis. Elevated levels of IL-1 beta have been reported in supernatants of monocyte cultures obtained from patients with psoriasis [112]. It was also noted that production of IL-1 beta by PBMCs correlated with psoriasis severity [112]. The study conducted by Johnston at al. [83] provided some interesting data. The authors demonstrated that obese patients with psoriasis had significantly higher serum concentration of IL-1 beta compared to the control group. However, no significant changes in the serum levels of IL-1 beta after the course of UVB treatment were noted [83].

\section{Plasminogen activator inhibitor 1 (PAI-1)}

PAI-1 is a potent inhibitor of fibrinolysis which interacts both with tissue-type (t-) and urokinase-type (u-) plasminogen activator which leads to inhibition of the conversion of plasminogen to plasmin $[184,185]$.

PAI-1 is a single chain glycoprotein and belongs to the family of serine protease inhibitors. PAI- 1 can be synthesized by a variety of cells including endothelial cells, hepatocytes, smooth muscle cells, adipocytes, and platelets [185].

Recently, it was noted that elevated levels of PAI-1 were related to abdominal obesity, insulin resistance, hypertriglyceridemia, thrombosis and cardiovascular disease [186, 187]. Elevated levels of PAI-1 correla- ted also with the development of type 2 diabetes [188]. Therefore, a prothrombotic state is implicated in the pathogenesis of metabolic syndrome [47].

Increased plasma levels of PAI-1 have been reported in patients with psoriasis, and the concentration of PAI-1 became lower in the course of the therapy [189]. In another study, elevated PAI-1 levels and reduced levels of t-PA were observed in patients with psoriasis [190]. A positive correlation between elevated levels of homocysteine and PAI-1 has been demonstrated in psoriatic patients [190]. It is worth noting that homocysteine may alter PAI-1 binding to endothelium [190].

These findings are particularly interesting because they stress the presence of fibrinolytic disturbances in psoriasis.

It is considered that PAI- 1 is a risk factor for cardiovascular disease and type 2 diabetes [191-195]. Therefore, it cannot be excluded that fibinolytic disturbances observed in psoriasis are involved in the development of cardiovascular complications in these patients.

\section{Uric acid}

Recently, it was noted that elevated serum levels of uric acid are associated with factors that contribute to metabolic syndrome, including: hypertriglyceridemia, obesity, hypertension and diabetes [196-199]. An attempt was made to evaluate whether the concentration of uric acid correlated with a single or increased number of elements which contribute to metabolic syndrome. In a large population study, it was demonstrated that increased serum levels of uric acid correlated with hypertriglyceridemia, abnormal waist circumference, high blood pressure and decreased HDL level. After controlling the results with BMI, elevated serum levels of uric acid still showed a correlation with hypertriglyceridemia, increased blood pressure and with decreased HDL levels [200].

Hyperuricemia has also been demonstrated in patients with psoriasis. It is thought that hyperuricemia may result from accelerated epidermal turn-over [201]. Studies conducted in the second half of the $20^{\text {th }}$ century which aimed to determine the relationship between hyperuricemia and psoriasis, produced conflicting results [201].

It has been demonstrated that an elevated serum concentration of uric acid is positively correlated with PASI, BMI and total body surface area compared to a normouricemic group [201]. In another study, an increased concentration of uric acid was found in patients with psoriasis compared to two other groups (patients with skin disorders other than psoriatic lesions, 
and a control group). After 12 weeks of therapy, a significant reduction of mean uric acid level was observed in patients with psoriasis. Furthermore, increased concentration of uric acid was accompanied by increased serum level of C-reactive protein. [202]. Hyperuricemia has also been reported in psoriatic arthritis [203].

It has been suggested that serum uric acid should be monitored in patients with psoriasis and metabolic syndrome [200-202]. However, a prospective study is required in order to determine if the prevention or treatment of hyperuricemia may affect the development of metabolic syndrome or the course of psoriasis.

\section{Lipid abnormalities}

Different lipid abnormalities are included in the pathogenesis of metabolic syndrome. One of them is an elevated concentration of Apo B. It is recognized that Apo $B$ is responsible for the accumulation of $L D L$ cholesterol within the endothelium; therefore, it is involved in the initiation of atherosclerotic plaques formation. Moreover, increased levels of Apo B are connected to an increased risk of development of atherosclerosis [204]. To date, few studies have demonstrated elevated levels of Apo B in psoriasis [39, 204]. However, there have also been studies which did not reveal any differences in Apo B concentration between patients with psoriasis and the healthy control group [39]. Increased levels of apolipoprotein A1 (Apo A1) have also been reported in patients with psoriasis [205]. It has been shown that an increased concentration of Apo A1 increases the risk of atherosclerosis [206]. Particularly interesting is the study conducted by Wilhelm et al. [207]. They observed that substitution of Apo A-1 to hypercholesterolemic mice lacking high density lipoprotein apolipoprotein A1 (HDL Apo A1) or LDLr(-/-) (low density lipoprotein receptor), apoA-I(-/-) (DKO) resulted in an increased percentage of Treg lymphocytes [207]. Other commonly reported lipid abnormalities in patients with psoriasis include: elevated LDL, total cholesterol and triglyceride levels [205, 208-211] as well as decreased HDL levels [211, 212]. The study published by Tekin et al. [208] indicates that oxidized low-density lipoprotein is accumulated in psoriatic skin lesions.

It is worth noting that, both in psoriasis and atherosclerosis, HDL becomes dysfunctional and has proinflammatory properties [213]. Additionally, CD209 ${ }^{+} / \mathrm{CD}_{163}{ }^{+}$dermal macrophages which are capable of engulfing oxidized lipids have been identified in psoriatic tissue. Moreover, it has been demonstrated that TPH-1 macrophages stimulated by a component of minimally oxidized LDL express IL-1, 6 , $15,17,23, \mathrm{VEGF}$ and cathelicidin, all of which are involved in pathogenesis of psoriasis [213]. This study indicated that host lipids and dermal macrophages are involved in the pathogenesis of psoriasis.

It is thought that lipid abnormalities are involved in the pathogenesis of psoriasis. Moreover, they are considered as factors that may lead to increased mortality due to cardiovascular complications. There have been many publications devoted to the role of lipids in psoriasis [39, 204], therefore in this review they will not be discussed in detail.

\section{C-reactive protein (CRP)}

A number of studies have demonstrated a link between the concentration of C-reactive protein and cardiovascular disease, BMI, waist to hip ratio, hypertriglyceridemia, increased levels of glucose, abnormal blood pressure, and insulin resistance [214-216].

Several studies have reported a correlation between increased levels of CRP and PASI [73, 217, 218]. Coimbra et al. [219] determined a prevalence of cardiovascular risk factors in patients with psoriasis. They demonstrated significantly higher levels of CRP compared to a control group. Although CRP concentration was reduced after the phototherapy, it still remained higher than in the control group. Considering these results, the authors suggested that in psoriasis there might be an inflammatory process which persists even after the therapy, and may lead to the development of atherogenic changes [219]. A positive correlation between elevated serum levels of high sensitivity of CRP (hs-CRP) and the degree of arterial stiffness in patients with psoriasis was reported in another study [220]. Moreover, increased concentration of hs-CRP seems to be an independent predictor of arterial stiffness. It has been suggested that the inflammatory process in psoriasis, which is characterized by elevated levels of CRP, is connected to increased arterial stiffness and premature development of atherosclerosis. These findings provide further evidence of a link between inflammation and cardiovascular diseases in patients with psoriasis [220]. This study is consistent with the research published by Ludwig et al. [221], which reported an increased prevalence and severity of coronary artery calcification as an indicator for cardiovascular disease in patients with psoriasis.

\section{Conclusions}

A large number of recently conducted studies have revealed the link between psoriasis and metabolic syndrome. It is worth noting that both psoriasis and metabolic syndrome are associated with inflammation, characterized by increased proinflammatory cy- 
tokines, alteration of adipokine levels, lipid abnormalities, hyperuricemia or a prothrombotic state. Therefore, it is considered that metabolic disturbances may be connected to immunological abnormalities, and that psoriasis may be considered as an immunometabolic disease.

The exact mechanism which could explain the link between psoriasis and metabolic disturbances has not been precisely recognized. Therefore, further studies are needed, designed to estimate the correlation between biochemical markers of metabolic syndrome and psoriasis, as well as to determine which of them could be used to predict the development of metabolic syndrome in patients with psoriasis. This research should cover reference groups selected by age, gender and BMI. The results of such studies could lead to a change of therapeutic strategies and improve psoriasis outcomes.

\section{Acknowledgement}

This project was funded by the Medical University of Lublin, Research Project no. DS 168/12 and DS 164/12. We would like to thank Professor Peter van de Kerkhof (Radboud University Nijmegen Medical Centre) for his guidelines and help during preparation of this manuscript.

\section{References}

1. Alsufyani MA, Golant AK, Lebwohl M. Psoriasis and the metabolic syndrome. Dermatol Ther. 2010;23:137-143.

2. Fitch E, Herper E, Schorkeva I, Kurtz SE, Blauvelt A. Pathophysiology of psoriasis recent advances on IL 23 nad TH 17 cytokines. Curr Rheumatol Rep. 2007;9:461-467.

3. Davidovici BB, Sattar N, Prinz JC et al. Psoriasis and systemic inflammatory diseases: potential mechanistic links between skin disease and co-morbid conditions. J Invest Dermatol. 2010;130:1785-1796.

4. Zhu K, Ye J, Wu M, Cheng H. Expression of Th1 and Th2 cytokine-associated transcription factors, T-bet and GATA-3, in peripheral blood mononuclear cells and skin lesions of patients with psoriasis vulgaris. Arch Dermatol Res. 2010;302:517-523.

5. Antonelli A, Fallahi P, Delle Sedie A et al. High values of Th1 (CXCL10) and Th2 (CCL2) chemokines in patients with psoriatic arthtritis. Clin Exp Rheumatol. 2009;27:22-27.

6. Jacob SE, Nassiri M, Kerdel FA, Vincek V. Simultaneous measurement of multiple Th1 and Th2 serum cytokines in psoriasis and correlation with disease severity. Mediators Inflamm. 2003;12:309-313.

7. Clarke LE, Helm KF, Hennessy J, Bruggeman RD, Clarke JT. Dermal dendritic cells in psoriasis, nummular dermatitis, and normal-appearing skin. J Am Acad Dermatol. 2011 Jun 11. Epub ahead of print.

8. Guttman-Yassky E, Lowes MA, Fuentes-Duculan J et al. Major differences in inflammatory dendritic cells and their products distinguish atopic dermatitis from psoriasis. J Allergy Clin Immunol. 2007;119:1210-1217.

9. Albanesi C, Scarponi C, Bosisio D, Sozzani S, Girolomoni G. Immune functions and recruitment of plasmacytoid dendritic cells in psoriasis. Autoimmunity. 2010;43:215-219.
10. Khayrullina T, Yen JH, Jing H, Ganea D. In vitro differentiation of dendritic cells in the presence of prostaglandin E2 alters the IL-12/IL-23 balance and promotes differentiation of Th17 cells. J Immunol. 2008;181:721-735.

11. Tan ZY, Bealgey KW, Fang Y, Gong YM, Bao S. Interleukin-23: immunological roles and clinical implications. Int J Biochem Cell Biol. 2009;41:733-735.

12. Lombardi V, Van Overtvelt L, Horiot S, Moingeon P. Human dendritic cells stimulated via TLR7 and/or TLR8 induce the sequential production of Il-10, IFN-gamma, and IL-17A by naive CD4 ${ }^{+}$T cells. J Immunol. 2009;182:3372-3379.

13. Korn T, Bettelli E, Oukka M, Kuchroo VK. IL-17 and Th17 Cells. Annu Rev Immunol. 2009;27:485-517.

14. Zhou L, Lopes JE, Chong MM et al. TGF-beta-induced Foxp3 inhibits $\mathrm{T}(\mathrm{H}) 17$ cell differentiation by antagonizing ROR-t function. Nature. 2008;453:236-240.

15. Chan JR, Blumenschein W, Murphy E et al. IL-23 stimulates epidermal hyperplasia via TNF and IL-20R2-dependent mechanisms with implications for psoriasis pathogenesis. J Exp Med. 2006;203:2577-2587.

16. Wolk K, Witte E, Wallace E et al. IL-22 regulates the expression of genes responsible for antimicrobial defense, cellular differentiation, and mobility in keratinocytes: a potential role in psoriasis. Eur J Immunol. 2006;36:1309-1323.

17. Wilson NJ, Boniface K, Chan JR et al. Development, cytokine profile and function of human interleukin 17-producing helper T cells. Nat Immunol. 2007;8:950-957.

18. Zaba LC, Cardinale I, Gilleaudeau $\mathrm{P}$ et al. Amelioration of epidermal hyperplasia by TNF inhibition is associated with reduced Th17 responses. J Exp Med. 2007;204:3183-3194.

19. Kryczek I, Bruce AT, Gudjonsson JE et al. Induction of IL-17+ $\mathrm{T}$ cell trafficking and development by IFN-gamma: mechanism and pathological relevance in psoriasis. J Immunol. 2008;181:4733-4741.

20. Lowes MA, Kikuchi T, Fuentes-Duculan J et al. Psoriasis vulgaris lesions contain discrete populations of Th1 and Th17 T cells. J Invest Dermatol. 2008;128:1207-1211.

21. Harper EG, Guo C, Rizzo H et al. Th17 cytokines stimulate CCL20 expression in keratinocytes in vitro and in vivo: implications for psoriasis pathogenesis. I Invest Dermatol. 2009;129:2175-2183.

22. Nograles KE, Zaba LC, Shemer A et al. IL-22-producing "T22" T cells account for upregulated IL-22 in atopic dermatitis despite reduced IL-17-producing $\mathrm{T}(\mathrm{H}) 17 \mathrm{~T}$ cells. J Allergy Clin Immunol. 2009;123:1244-1251e2.

23. Nograles KE, Zaba LC, Guttman-Yassky E et al. Th17 cytokines, interleukin (IL)-17 and IL-22 modulate distinct inflammatory and keratinocyte-response pathways. Br J Dermatol. 2008;159:1092-1102.

24. Zhang N, Pan HF, Ye DQ. Th22 in inflammatory and autoimmune disease: prospects for therapeutic intervention. $\mathrm{Mol}$ Cell Biochem. 2011;353:41-46.

25. Fujita H, Nograles KE, Kikuchi T, Gonzalez J, Carucci JA, Krueger JG. Human Langerhans cells induce distinct IL-22-producing $\mathrm{CD}^{+}{ }^{+} \mathrm{T}$ cells lacking IL-17 production. Proc Natl Acad Sci USA. 2009;106:21795-21800.

26. Lowes MA, Bowcock AM, Krueger JG. Pathogenesis and therapy of psoriasis. Nature. 2007;445:866-873.

27. Guttman-Yassky E, Krueger JG. Psoriasis: evolution of pathogenic concepts and new therapies through phases of translational research. Br J Dermatol. 2007;157:1103-1115.

28. Taams L, Vukmanovic-Stejic M, Salmon M, Akbar A. Immune regulation by $\mathrm{CD} 4{ }^{+} \mathrm{CD} 25^{+}$regulatory T cells: implications for transplantation tolerance. Transpl Immunol. 2003;11:277-285. 
29. Mutis T, Aarts-Riemens T, Verdonck LF. The association of $\mathrm{CD} 25$ expression on donor $\mathrm{CD} 8^{+}$and $\mathrm{CD} 4^{+} \mathrm{T}$ cells with graftversus-host disease after donor lymphocyte infusions. Haematologica. 2005;90:1389-1395.

30. Zorn E, Kim HT, Lee SJ et al. Reduced frequency of FOXP3 ${ }^{+}$ $\mathrm{CD} 4{ }^{+} \mathrm{CD} 25^{+}$regulatory $\mathrm{T}$ cells in patients with chronic graft-versus-host disease. Blood . 2005;106:2903-2911.

31. Liyanage UK, Moore TT, Joo HG et al. Prevalence of regulatory $\mathrm{T}$ cells is increased in peripheral blood and tumor microenvironment of patients with pancreas or breast adenocarcinoma. J Immunol. 2002;169:2756-2761.

32. Woo EY, Yeh H, Chu CS et al. Cutting edge: Regulatory $\mathrm{T}$ cells from lung cancer patients directly inhibit autologous T cell proliferation. J Immunol. 2002;168:4272-4276.

33. Zou W. Regulatory T cells, tumour immunity and immunotherapy. Nat Rev Immunol. 2006;6:295-307.

34. Sugiyama H, Gyulai R, Toichi E et al. Dysfunctional blood and target tissue $\mathrm{CD} 4{ }^{+} \mathrm{CD} 25^{\text {high }}$ regulatory $\mathrm{T}$ cells in psoriasis: mechanism underlying unrestrained pathogenic effector T cell proliferation. J Immuno. 2005;174:164-173.

35. Bovenschen HJ, van Vlijmen-Willems IM, van de Kerkhof $\mathrm{PC}$, van Erp PE. Identification of lesional $\mathrm{CD} 4^{+} \mathrm{CD} 25^{+}$ Foxp $3^{+}$regulatory $\mathrm{T}$ cells in Psoriasis. Dermatology. 2006;213:111-117.

36. Cheng X, Yu X, Ding YJ, et al. The Th17/Treg imbalance in patients with acute coronary syndrome. Clin Immunol. 2008:127:89-97.

37. Icen M, Crowson CS, McEvoy MT, Dann FJ, Gabriel SE, Kremers HM. Trends in incidence of adults - onset psoriasis over three decades: a population-based study. J Am Acad Dermatol. 2009;60:394-401.

38. Wilson FC, Icen M, Crowson CS, McEvoy MT, Gabriel SE, Kremers HM. Incidence and clinical predictors of psoriatic arthritis in patients with psoriasis: a population based study. Arhritis Rheum. 2009;61:233-239.

39. Pietrzak A, Chodorowska G, Szepietowski J, Zalewska-Janowska A, Krasowska D, Hercogova J. Psoriasis and serum lipid abnormalities. Dermatol Ther. 2010;23:160-173.

40. Pietrzak A, Jastrzebska I, Krasowska D et al. Serum pancreatic lipase [EC 3.1.1.3] activity, serum lipid profile and peripheral blood dendritic cell populations in normolipidemic males with psoriasis. J Mol Catal B Enzym. 2006;40:144-154.

41. Neinman AL, Shin DB, Wang X, Margolis DJ, Troxel AB Gelfand JM. Prevelance of cardiovascular risk factors in patients with psoriasis. J Am Acad Dermatol. 2006;55:829-835.

42. Späh F. Inflammation in atherosclerosis and psoriasis: common pathogenic mechanisms and the potential for an integrated treatment approach. Br J Dermatol. 2008;159(Suppl 2):10-17.

43. Cohen AD, Gilutz H, Henkin Y et al. Psoriasis and the Metabolic Syndrome. Acta Derm Venereol. 2007;87:506-509.

44. Gisondi P, Tessari G, Conti A et al. Prevalence of metabolic syndrome in patients with psoriasis: a hospital-based casecontrol study. Br J Dermatol. 2007;157:68-73.

45. Sommer DM, Jenisch S, Suchan M, Christophers E, Weichenthal M. Increased prevalence of the metabolic syndrome in patients with moderate to severe psoriasis. Arch Dermatol Res. 2006;298:321-328.

46. Eckel RH, Grundy SM, Zimmet PZ. The metabolic syndrome. Lancet. 2005;365:1415-1428.

47. The IDF consensus worldwide definition of the metabolic syndrome at: http://www.idf.org/webdata/docs/MetSyndrome _FINAL.pdf. Accessed October, 72011.

48. Love TJ, Qureshi AA, Karlson EW, Gelfand JM, Choi HK. Prevalence of the metabolic syndrome in psoriasis: results from the National Health and Nutrition Examination Survey, 2003-2006. Arch Dermatol. 2011;147:419-424.

49. Nisa N, Qazi MA. Prevalence of metabolic syndrome in patients with psoriasis. Indian J Dermatol Venereol Leprol. 2010;76:662-665.

50. Mebazaa A, El Asmi M, Zidi W et al. Metabolic syndrome in Tunisian psoriatic patients: prevalence and determinants. J Eur Acad Dermatol Venereol. 2011;25:705-709.

51. Raychaudhuri SK, Chatterjee S, Nguyen C, Kaur M, Jialal I, Raychaudhuri SP. Increased prevalence of the metabolic syndrome in patients with psoriatic arthritis. Metab Syndr Relat Disord. 2010;8:331-334.

52. Azfar RS, Gelfand JM. Psoriasis and metabolic disease: epidemiology and pathopysiology. Curr Opin Rheumatol. 2008;20:416-422.

53. Sterry W, Storber BE, Menter A. International Psoriasis Cuncil. Obesity in psoriasis, the metabolic, clinical and therapeutic implications. Report of an interdisciplinary conference and review. Br J. Dermatol. 2007;157:649-655.

54. Lindegírd B. Diseases associated with psoriasis in a general population of 159,200 middle-aged, urban, native Swedes. Dermatologica. 1986;172:298-304

55. Naldi L, Chatenoud L, Linder D et al. Cigarette smoking, body mass index, and stressful life events as risk factors for psoriasis: results from an Italian case-control study. J Invest Dermatol. 2005;125:61-67.

56. Wozniak SE, Gee LL, Wachtel MS, Frezza EE. Adipose tissue: the new endocrine organ? A review article. Dig Dis Sci. 2009;54:1847-1856.

57. Gnacińska M, Małgorzewicz S, Stojek M, Łysiak-Szydłowska W, Sworczak K. Role of adipokines in complications related to obesity: a review. Adv Med Sci. 2009;54:150-157.

58. Chen Y, Wu C, Shen J et al. Psoriasis independently associated with hyperletynemia contributing to metabolic syndrome. Arch Dermatol. 2008;144:1571-1575.

59. Ouchi N, Walsh K. Adiponectin as an anti-inflammatory factor. Clin Chim Acta. 2007;380:24-30.

60. Hara K, Boutin P, Mori Y et al. Genetic variation in the gene encoding adiponectin is associated with an increased risk of type 2 diabetes in the Japanese population. Diabetes. 2002;51:536-540.

61. Hara K, Horikoshi M, Yamauchi T et al. Measurement of the high-molecular weight form of adiponectin in plasma is useful for the prediction of insulin resistance and metabolic syndrome. Diabetes Care. 2006;29:1357-1362.

62. Shibata R, Ouchi N, Murohara T. Adiponectin and cardiovascular disease. Circ J. 2009;73:608-614.

63. Gerdes S, Rostami-Yazdi M, Mrowietz U. Adipokines and psoriasis. Exp Dermatol. 2011;20:81-87

64. Shibata R, Sato K, Pimentel DR et al. Adiponectin protects against myocardial ischemia-reperfusion injury through AMPK- and COX-2-dependent mechanisms. Nat Med. 2005;11:1096-1103.

65. Dekker JM, Funahashi T, Nijpels G et al. Prognostic value of adiponectin for cardiovascular disease and mortality. J Clin Endocrinol Metab. 2008;93:1489-1496.

66. Kadowaki T, Yamauchi T, Kubota N. Adiponectin and adiponectin receptors in insulin resistance, diabetes, and the metabolic syndrome. J Clin Invest. 2006;106:1784-1792.

67. Targher G, Bertolini L, Scala L. Decreased plasma adiponectin contractions are closely associated with nonalcoholic hepatic steatosis in obese individuals. Clin Endocrinol. 2004;61:700-703.

68. Fantuzzi G. Adiponectin and inflammation: consensus and controversy. J Allergy Clin Immunol. 2008;121:326-330. 
69. Takahashi H, Tsuji H, Takahashi I, Hashimoto Y, Ishida-Yamamoto A, Iizuka H. Plasma adiponectin and leptin levels in Japanese patients with psoriasis. Br J Dermatol. 2008;159:1207-1208.

70. Shibata S, Saeki H, Tada Y, Karakawa M, Komine M, Tamaki K. Serum high molecular weight adiponectin levels are decreased in psoriasis patients. J Dermatol Sci. 2009;55: 62-63.

71. Shibata S, Tada Y, Hau C et al. Adiponectin as an anti-inflammatory factor in the pathogenesis of psoriasis: induction of elevated serum adiponectin levels following therapy. $\mathrm{Br}$ J Dermatol. 2011;164:667-670.

72. Kaur S, Zilmer K, Kairane C, Kals M, Zilmer M. Clear differences in adiponectin level and glutathione redox status revealed in obese and normal-weight patients with psoriasis. Br J Dermatol. 2008;159:1364-1367.

73. Coimbra S, Oliveira H, Reis $\mathrm{F}$ et al. Circulating adipokine levels in Portuguese patients with psoriasis vulgaris according to body mass index, severity and therapy. J Eur Acad Dermatol Venereol. 2010;24:1386-1394.

74. Wang Y, Chen J, Zhao Y, Geng L, Song F, Chen HD. Psoriasis is associated with increased levels of serum leptin. $\mathrm{Br}$ J Dermatol. 2008;158:1134-1135.

75. Klok MD, Jakobsdottir S, Drent ML. The role of leptin and ghrelin in the regulation of food intake and body weight in humans: a review. Obes Rev. 2007;8:21-34.

76. Koerner A, Kratzsch J, Kiess W. Adipocytokines: leptin the classical, resistin - the controversical, adiponectin - the promising, and more to come. Best Pract Res Cl En. 2005;19:4525-4546.

77. Poeggeler B, Schulz C, Pappolla MA et al. Leptin and the skin: a new frontier. Exp Dermatol. 2010;19:12-18.

78. El-Haschimi K, Pierroz DD, Hileman SM, Bjǔrbaek C, Flier JS. Two defects contribute to hypothalamic leptin resistance in mice with diet-induced obesity. J Clin Invest. 2000;105:1827-1832 .

79. Moran O, Phillip M. Leptin: obesity, diabetes and other peripheral effects - a review. Pediatr Diabetes. 2003;4:101-109.

80. Koh KK, Park SM, Quon MJ. Leptin and cardiovascular disease: response to therapeutic interventions. Circulation. 2008;117:3238-3249.

81. Beltowski J. Leptin and atherosclerosis. Atherosclerosis. 2006;189:47-60.

82. Wolk R, Berger P, Lennon RJ, Brilakis ES, Johnson BD, Somers VK. Plasma leptin and prognosis in patients with established coronary atherosclerosis. J Am Coll Cardiol. 2004;44:1819-1824

83. Johnston A, Arnadottir S, Gudjonsson JE et al. Obesity in psoriasis: Leptin and restin as mediators of cutaneous inflammation. Br J Dermatol. 2008;159:342-351.

84. Maradit-Kremers H, Nicola PJ, Crowson CS, Ballman KV, Gabriel SE. Cardiovascular death in rheumatoid arthritis: a population-based study. Arthritis Rheum. 2005;52:722-732.

85. Boehncke S, Thaci D, Beschmann Het al. Psoriasis patients show signs of insulin resistance. Br J Dermatol. 2007;157:1249-1251.

86. Filkova M, Haluzík M, Gay S, Senolt L. The role of resistin as a regulator of inflammation: Implications for various human pathologies. Clin Immunol. 2009;133:157-170.

87. Curat CA, Wegner V, Sengenès $C$ et al. Macrophages in human visceral adipose tissue: increased accumulation in obesity and a source of resistin and visfatin. Diabetologia. 2006;49:744-747.

88. Osawa H, Onuma H, Ochi M et al. Resistin SNP-420 determines its monocyte mRNA and serum levels inducing type 2 diabetes. Biochem Biophys Res Commun. 2005;335:596-602.
89. Minn AH, Patterson NB, Pack S et al. Resistin is expressed in pancreatic islets. Biochem Biophys Res Commun. 2003;310:641-645.

90. Schäffler A, Ehling A, Neumann E et al. Adipocytokines in synovial fluid. JAMA. 2003;290:1709-1710.

91. Yura S, Sagawa N, Itoh H et al. Resistin is expressed in the human placenta.J Clin Endocrinol Metab. 2003;88:1394-1397.

92. Senolt L, Housa D, Vernerov $\alpha \mathrm{Z}$ et al. Resistin in rheumatoid arthritis synovial tissue, synovial fluid and serum. Ann Rheum Dis. 2007;66:458-463.

93. Bokarewa M, Nagaev I, Dahlberg L, Smith U, Tarkowski A. Resistin, an adipokine with potent proinflammatory properties. J Immunol. 2005;174:5789-5795.

94. Kaser S, Kaser A, Sandhofer A, Ebenbichler CF, Tilg H, Patsch JR. Resistin messenger-RNA expression is increased by proinflammatory cytokines in vitro. Biochem Biophys. Res Commun. 2003;309:286-290.

95. Adeghate E. An update on the biology and physiology of resistin. Cell Mol Life Sci. 2004;61:2485-2496.

96. Rea R, Donnelly R. Resistin: an adipocyte-derived hormone. Has it a role in diabetes and obesity? Diabetes Obes Metab. 2004;6:163-170.

97. Dyck DJ, Heigenhauser GJ, Bruce CR. The role of adipokines as regulators of skeletal muscle fatty acid metabolism and insulin sensitivity. Acta Physiol (Oxf). 2006;186:5-16.

98. McTernan PG, Kusminski CM, Kumar S. Resistin. Curr Opin Lipidol. 2006;17:170-175.

99. Heilbronn LK, Rood J, Janderova L et al. Relationship between serum resistin concentrations and insulin resistance in nonobese, obese, and obese diabetic subjects. J Clin Endocrinol Metab. 2004;89:1844-1848.

100. Savage DB, Sewter CP, Klenk ES et al. Resistin/Fizz3 expression in relation to obesity and peroxisome proliferator-activated receptor-gamma action in humans. Diabetes. 2001;50:2199-202.

101. Korah TE, Ibrahim HH, Badr EA, ElShafie MK. Serum resistin in acute myocardial infarction patients with and without diabetes mellitus. Postgrad Med J. 2011;87:463-467.

102. Hamminga EA, van der Lely AJ, Neumann HA, Thio HB. Chronic inflammation in psoriasis and obesity: implications for therapy. Med Hypotheses. 2006;67:768-773.

103. Kojima M, Kangawa K. Ghrelin: structure and function. Physiol Rev. 2005;85:495-522.

104. Gauna C, Delhanty PJ D, Hofland LJ et al. Ghrelin stimulates, whereas des-octanoyl ghrelin inhibits, glucose output by primary hepatocytes. J Clin Endocrinol Metab. 2005;90:1055-1060.

105. Hosoda H, Kojima M, Mizushima T, Shimizu S, Kangawa K. Structural divergence of human ghrelin. Identification of multiple ghrelin-derived molecules produced by post-translational processing. J Biol Chem. 2003;278:64-70.

106. Meier U, Gressner AM. Endocrine regulation of energy metabolism: review of pathobiochemical and clinical chemical aspects of leptin, ghrelin, adiponectin, and resistin. Clin Chem. 2004;50:1511-1525.

107. Pulkkinen L, Ukkola O, Kolehmainen M, Uusitupa M. Ghrelin in Diabetes and Metabolic Syndrome. Int J Pept. 2010;2010:1-11.

108. Pöykkö SM, Kellokoski E, Hörkkö S, Kauma H, Kesäniemi YA, Ukkola O. Low plasma ghrelin is associated with insulin resistance, hypertension, and the prevalence of type 2 diabetes. Diabetes. 2003;52:2546-2553.

109. Barazzoni R, Zanetti M, Ferreira C et al. Relationships between desacylated and acylated ghrelin and insulin sensitivity in the metabolic syndrome. J Clin Endocrinol Metab. 2007;92:3935-3940. 
110. Kershaw EE, Flier JS. Adipose tissue as an endocrine organ. J Clin Endocrinol Metab. 2004;89:2548-2556.

111. Fujishima S, Watanabe H, Kawaguch M et al. Involvement of IL-17F via the induction of IL-6 in psoriasis. Arch Dermatol Res. 2010;302:499-505.

112. Pietrzak AT, Zalewska A, Chodorowska G et al. Cytokines and anticytokines in psoriasis. Clin Chim Acta. 2008;394:7-21.

113. Eder K, Baffy N, Falus A, Fulop AK. The major inflammatory mediator interleukin-6 and obesity. Inflamm Res. 2009;58:727-736.

114. Fernandez-Real JM, Ricart W. Insulin resistance and chronic cardiovascular inflammatory syndrome. Endocr Rev. 2003;24:278-301.

115. Esteve E, Castro A, López-Bermejo A, Vendrell J, Ricart W, Fernandez-Real JM. Serum interleukin-6 correlates with endothelial dysfunction in healthy men independently of insulin sensitivity. Diabetes Care. 2007;30:939-945.

116. Nishida M, Moriyama T, Ishii K et al. Effects of IL-6, adiponectin, CRP and metabolic syndrome on subclinical atherosclerosis. Clin Chim Acta. 2007;384:99-104.

117. Goodman WA, Levine AD, Massai JV, Sugiyama H, McCornick TS, Cooper KD. IL-6 Signaling in Psoriasis Prevents Immune Suppression by Regulatory T Cells. J Immun. 2009;183:3170-3176.

118. Sakai R, Matsui S, Fukushima M, Yasuda H, Miyauchi H, Miyachi Y. Prognostic factor analysis for plaque psoriasis. Dermatology. 2005;211:103-106.

119. Kaur S, Zilmer K, Leping V, Zilmer M. The levels of adiponectin and leptin and their relation to other markers of cardiovascular risk in patients with psoriasis. J Eur Acad Dermatol Venereol. 2011;25:1328-1333.

120. Aksentijevich I, Masters SL, Ferguson PJ et al. An autoinflammatory disease with deficiency of the interleukin-1-receptor antagonist. N Engl J Med. 2009;360:2426-2437.

121. Cunliffe WJ, Holland DB, Clark SM, Stables GI. Comedogenesis: some aetiological, clinical and therapeutic strategies. Dermatology. 2003;206:11-16.

122. Yu R, Kim CS, Kawada T, Kwon TW, Lim TH, Kim YW, Kwon BS. Involvement of leukotactin-1, a novel CC chemokine, in human atherosclerosis. Atherosclerosis. 2004;174:35-42.

123. Shin MJ, Lee KH, Chung JH et al. Circulating IL-8 levels in heart failure patients with and without metabolic syndrome. Clin Chim Acta. 2009;405:139-142.

124. Gerhardt CC, Romero IA, Cancello R, Camoin L, Strosberg AD. Chemokines control fat accumulation and leptin secretion by cultured human adipocytes. Mol Cell Endocrinol. 2001;175:81-92.

125. Kobashi C, Asamizu S, Ishiki M et al. Inhibitory effect of IL-8 on insulin action in human adipocytes via MAP kinase pathway. J Inflamm (Lond). 2009;27:25.

126. Pietrzak A, Kozioł-Montewka M, Lecewicz-Toruń B, Krasowska $\mathrm{D}$. Is there any correlation between the total number of neutrophils in plasma and concentration of interleukin- 8 in psoriatic patients? Med Sci Monit. 2000;6:867-870.

127. Coimbra S, Oliveira H, Reis F et al. Interleukin (IL)-22, IL-17, IL-23, IL-8, vascular endothelial growth factor and tumour necrosis factor- $\alpha$ levels in patients with psoriasis before, during and after psoralen-ultraviolet A and narrowband ultraviolet B therapy. Br J Dermatol. 2010;163:1282-1290.

128. Takahashi H, Tsuji H, Hashimoto Y, Ishida-Yamamoto A, Iizuka H. Serum cytokines and growth factor levels in Japanese patients with psoriasis. Clin Exp Dermatol. 2010;35:645-649.

129. Ozawa M, Terui T, Tagami H. Localization of IL-8 and complement components in lesional skin of psoriasis vulgaris and pustulosis palmaris et plantaris. Dermatology. 2005;211:249-255.
130. Esposito K, Nappo F, Giugliano F et al. Cytokine Milieu Tends Toward Inflammation in Type 2 Diabetes. Diabetes Care. 2003;26:51647.

131. Ware CF. The TNF Superfamily - 2008. Cytokine Growth Factor Rev. 2008;19:183-186.

132. Yamaguchi K, Higashiura K, Ura N et al. The effect of tumor necrosis factor-alpha on tissue specificity and selectivity to insulin signaling. Hypertes Res. 2003;26:389-396.

133. Ruan H, Miles PD, Ladd CM et al. Profiling gene transcription in vivo reveals adipose tissue as an immediate target of tumor necrosis factor-alpha: implications for insulin resistance. Diabetes. 2002;51:3176-3188.

134. Cai D, Yuan M, Frantz DF et al. Local and systemic insulin resistance resulting from hepatic activation of IKK-beta and NF-kappaB. Nat Med. 2005;11:183-190.

135. Wei Y, Chen K, Whaley-Connel AT, Ibdah JA, Sowers JR. Skeletal muscle insulin resistance: role of inflammatory cytokines and reactive oxygen species. AJP-Regu Physiol. 2008;294:673-680.

136. Shin JY, Kim SY, Jeung MJ et al. Serum adiponectin, C-reactive protein and TNF-alpha levels in obese Korean children. J Pediatr Endocrinol Metab. 2008;21:23-29.

137. Marques-Vidal P, Bochud M, Bastardot F et al. Association between inflammatory and obesity markers in a Swiss population-based sample (CoLaus study). Endokrinologie und Metabolismus 79. Jahrestagung der Schweizerischen Gesellschaft für Innere Medizin Palais de Beaulieu, Lausanne 11.05.2011-13.05.2011. Abstract.

138. Dinh W, Füth R, Nickl W et al. Elevated plasma levels of TNF-alpha and interleukin-6 in patients with diastolic dysfunction and glucose metabolism disorders. Cardiovasc Diabetol. 2009;8:58.

139. Arican O, Aral M, Sasmaz S, Ciragil P. Serum levels of TNF-alpha, IFN-gamma, IL-6, IL-8, IL-12, IL-17, and IL-18 in patients with active psoriasis and correlation with disease severity. Mediators Inflamm. 2005;2005:273-279.

140. Saraceno R, Schipani C, Mazzotta A et al. Effect of anti-tumor necrosis factor-alpha therapies on body mass index in patients with psoriasis. Pharmacol Res. 2008;57:290-295.

141. Briot K, Garnero P, Le Henanff A, Dougados M, Roux C. Body weight, body composition, and bone turnover changes in patients with spondyloarthropathy receiving anti-tumour necrosis factor alpha treatment. Ann Rheum Dis. 2005;64:1137-1140.

142. Gisondi P, Cotena C, Tessari G, Girolomoni G. Anti-tumour necrosis factor-alpha therapy increases body weight in patients with chronic plaque psoriasis: a retrospective cohort study. J Eur Acad Dermatol Venereol. 2008;22:341-344.

143. Nakajima H, Nakajima K, Tarutami M, Morishige R, Sano S. Kinetics of circulating Th17 cytokines and adipokines in psoriasis patients. Arch Dermatol Res .2011;303:451-455.

144. Yamada H. Current perspectives on the role of IL-17 in autoimmune disease. J In Xamm Res. 2010;3:33-44.

145. Hwang SY, Kim JY, Kim KW et al. IL-17 induces production of IL-6 and IL- 8 in rheumatoid arthritis synovial fibroblasts via NF-kappaB- and PI3-kinase/Akt-dependent pathways. Arthritis Res Ther. 2004;6:120-128.

146. Lubberts E. IL-17/Th17 targeting: on the road to prevent chronic destructive arthritis? Cytokine. 2008;41:84-91.

147. Witowski J, Ksiazek K, Jorres A. Interleukin 17: a mediator of inflammatory responses. Cell Mol Life Sci. 2004;61:567-579.

148. Albanesi C, Scarponi C, Cavani A, Federici M, Nasorri F, Girolomoni G. Interleukin-17 is produced by both Th1 and Th2 lymphocytes, and modulates interferon-gamma- and in- 
terleukin-4-induced activation of human keratinocytes. $J$ Invest Dermatol. 2000;115:81-87.

149. Sumarac-Dumanovic M, Stevanovic D, Ljubic A. Increased activity of interleukin-23/interleukin-17 proinflammatory axis in obese women. Int. J. Obes. (Lond). 2009;33:151-156.

150. Zúniga LA, Shen WJ, Joyce-Shaikh B et al. IL-17 regulates adipogenesis, glucose homeostasis, and obesity. J Immunol. 2010;185:6947-6959.

151. Arababadi MK, Nosratabadi R, Hassanshahi G et al. Nephropathic complication of type-2 diabetes is following pattern of autoimmune diseases? Diabetes Res Clin Pract. 2010;87:33-37.

152. Armstrong AW, Voyles SV, Armstrong EJ, Fuller EN, Rutledge JC. A tale of two plaques: convergent mechanisms of T-cell-mediated inflammation in psoriasis and atherosclerosis. Exp Dermatol. 2011;20:544-549.

153. Hashmi S, Zeng QT. Role of interleukin-17 and interleukin-17-induced cytokines interleukin- 6 and interleukin-8 in unstable coronary artery disease. Coron Artery Dis. 2006;17:699-706.

154. Jafarzadeh A, Esmaeeli-Nadimi A, Nough H, Nemati M, Rezayati MT. Serum levels of interleukin (IL)-13, IL-17 and IL-18 in patients with ischemic heart disease. Anadolu Kardiyol Derg. 2009;9:75-83.

155. Surendar J, Aravindhan V, Rao MM, Ganesan A, Mohan V. Decreased serum interleukin-17 and increased transforming growth factor- $\beta$ levels in subjects with metabolic syndrome (Chennai Urban Rural Epidemiology Study-95). Metabolism. 2011;60:586-590.

156. Lin AM, Rubin CJ, Khandpur R et al. Mast cells and neutrophils release IL-17 through extracellular trap formation in psoriasis. J Immunol. 2011;187:490-500.

157. Zaba LC, Su $\alpha$ rez-Farińas M, Fuentes-Duculan J et al. Effective treatment of psoriasis with etanercept is linked to suppression of IL-17 signaling, not immediate response TNF genes. J Allergy Clin Immunol. 2009;124:1022-1030.

158. Nakanishi K, Yoshimoto T, Tsutsui H, Okamura H. Interleukin-18 is a unique cytokine that stimulates both Th1 and Th2 responses depending on its cytokine milieu. Cytokine Growth Factor Rev. 2001;12:53-72.

159. Ericson P, Lindén A, Riise GC. BAL levels of interleukin-18 do not change before or during acute rejection in lungtransplant recipients. Respir Med. 2004;98:159-163.

160. Weiss TW, Seljeflot I, Hjerkinn EM, Arnesen H. Adipose tissue pro-inflammatory gene expression is associated with cardiovascular disease. Int J Clin Pract. 2011;65:939-944.

161. Skurk T, Kolb H, Müller-Scholze S, Röhrig K, Hauner H, Herder $\mathrm{C}$. The proatherogenic cytokine interleukin-18 is secreted by human adipocytes. Eur J Endocrinol. 2005;152:863-868.

162. Packard RR, Libby P. Inflammation in atherosclerosis: from vascular biology to biomarker discovery and risk prediction. Clin Chem. 2008;54:24-38.

163. Mallat Z, Corbaz A, Scoazec A et al. Expression of interleukin-18 in human atherosclerotic plaques and relation to plaque instability. Circulation. 2001;104:1598-1603.

164. Blankenberg S, Luc G, Ducimetičre P et al; PRIME Study Group. Interleukin-18 and the risk of coronary heart disease in European men: the Prospective Epidemiological Study of Myocardial Infarction (PRIME). Circulation. 2003;108:2453-2459.

165. Blankenberg S, Tiret L, Bickel C et al. AtheroGene Investigators. Interleukin-18 is a strong predictor of cardiovascular death in stable and unstable angina. Circulation. 2002;106:24-30.

166. Thorand B, Kolb H, Baumert J et al. Elevated levels of interleukin-18 predict the development of type 2 diabetes: results from the MONICA/KORA Augsburg Study, 1984-2002. Diabetes. 2005;54:2932-2938.
167. Hung J, McQuillan BM, Chapman CM, Thompson PL, Beilby JP. Elevated interleukin-18 levels are associated with the metabolic syndrome independent of obesity and insulin resistance. Arterioscler Thromb Vasc Biol. 2005;25:1268-1273.

168. Sun L, Hu FB, Yu Z et al. Lean body mass, interleukin 18, and metabolic syndrome in apparently healthy Chinese. PLoS One. 2011;6:e18104.

169. McKenzie RC, Boyce F, Szepietowski J et al. Psoriatic epidermis expresses high levels of Interleukin 18 (IL-18), IL-18 receptor mRNA and IL-18 protein. Derm Klin. 2002;4:17-23.

170. Pietrzak A, Lecewicz-Toruń B, Roliński J. Interleukin-18 serum concentration in patients with psoriasis triggered by infection. Ann Univ Mariae Curie Sklodowska Med. 2002;57:484-490.

171. Pietrzak A, Lecewicz-Torun B, Chodorowska G, Roliński J. Interleukin-18 levels in the plasma of psoriatic patients correlate with the extent of skin lesions and the PASI score. Acta Dermato-Venereologica. 2003;83:262-265.

172. Pietrzak A, Roliński J, Junak-Bojarska A et al. Plasma level of interleukin 18 in psoriatic patients during topical treatment. Derm Klin. 2004;6:75-78.

173. Flisiak I, Zaniewski P, Chodynicka B. Plasma TGF-beta1, TIMP-1, MMP-1 and IL-18 as a combined biomarker of psoriasis activity. Biomarkers. 2008;13:549-556.

174. Companjen AR, van der Velden VH, Vooys A, Debets R, Benner R, Prens EP. Human keratinocytes are major producers of IL-18: predominant expression of the unprocessed form. Eur Cytokine Netw. 2000;11:383-390.

175. van de Kerkhof PC. Novel biologic therapies in development targeting IL-12/IL-23. J Eur Acad Dermatol Venereol. 2010;24(Suppl 6):5-9.

176. Sato K, Suematsu A, Okamoto K et al. Th17 functions as an osteoclastogenic helper T cell subset that links T cell activation and bone destruction. J Exp Med. 2006;203:2673-2682.

177. Yago T, Nanke Y, Kawamoto M et al. IL-23 induces human osteoclastogenesis via IL-17 in vitro, and anti-IL-23 antibody attenuates collagen-induced arthritis in rats. Arthritis Res Ther. 2007;9:R96.

178. Wiekowski MT, Leach MW, Evans EW et al. Ubiquitous transgenic expression of the IL-23 subunit p19 induces multiorgan inflammation, runting, infertility, and premature death. J Immunol. 2001;166:7563-7570.

179. Nakajima K, Kanda T, Takaishi M et al. Distinct roles of IL-23 and IL-17 in the development of psoriasis-like lesions in a mouse model. J Immunol. 2011;186:4481-4489.

180. Maedler K, Dharmadhikari G, Schumann DM, Størling J. Interleukin-targeted therapy for metabolic syndrome and type 2 diabetes. Handb Exp Pharmacol. 2011;203:257-278.

181. Jager J, Grémeaux T, Cormont M, Le Marchand-Bruste Y, Tanti JF. Interleukin-1beta-induced insulin resistance in adipocytes through down-regulation of insulin receptor substrate1 expression. Endocrinology. 2007;148:241-251.

182. Juge-Aubry CE, Somm E, Chicheportiche R et al. Regulatory effects of interleukin (IL)- 1 , interferon- $\beta$, and IL-4 on the production of IL-1 receptor antagonist by human adipose tissue. J Clin Endocrinol Metab. 2004:89:2652-2658.

183. Spranger J, Kroke A, Möhlig M et al. Inflammatory cytokines and the risk to develop type 2 diabetes: results of the prospective population-based European Prospective Investigation into Cancer and Nutrition (EPIC)-Potsdam Study. Diabetes. 2003;52:812-817.

184. Annecke K, Schmitt M, Euler U et al. uPA and PAI in breast cancer: review of their clinical utility and current validation in the prospective NNBC -3 trial. Adv Clin Chem. 2008;45:31-45. 
185. Binder BR, Christ G, Gruber F et al. Plasminogen Activator Inhibitor 1: Physiological and Pathophysiological Roles. News Physiol Sci. 2002;17:56-61.

186. Trost S, Pratley R, Sobel B. Impaired fibrinolysis and risk for cardiovascular disease in the metabolic syndrome and type 2 diabetes. Curr Diab Rep. 2006;6:47-54.

187. Black PH, Garbutt LD. Stress, inflammation and cardiovascular disease. J Psychosom Res. 2002;52:1-23.

188. Festa A, D'Agostino R Jr, Tracy RP, Haffner SM. Insulin Resistance Atherosclerosis Study. Elevated levels of acutephase proteins and plasminogen activator inhibitor-1 predict the development of type 2 diabetes: the insulin resistance atherosclerosis study. Diabetes. 2002;51:1131-1137.

189. Nielsen HJ, Christensen IJ, Svendsen MN et al. Elevated plasma levels of vascular endothelial growth factor and plasminogen activator inhibitor-1 decrease during improvement of psoriasis. Inflamm Res. 2002;51:563-567.

190. Vanizor Kural B, Orem A, Cimşit G, Uydu HA, Yandi YE, Alver A. Plasma homocysteine and its relationships with atherothrombotic markers in psoriatic patients. Clin Chim Acta. 2003;332:23-30.

191. Alessi MC, Bastelica D, Morange P et al. Plasminogen activator inhibitor 1 , transforming growth factor-beta 1 , and $\mathrm{BMI}$ are closely associated in human adipose tissue during morbid obesity. Diabetes. 2000;49:1374-1380

192. Segarra A, Chacón P, Martinez-Eyarre C et al. Circulating levels of plasminogen activator inhibitor type-1, tissue plasminogen activator, and thrombomodulin in hemodialysis patients: biochemical correlations and role as independent predictors of coronary artery stenosis. J Am Soc Nephrol. 2001;12:1255-1263.

193. Kralisch S, Sommer G, Deckert CM et al. Adipokines in diabetes and cardiovascular diseases. Minerva Endocrinol. 2007;32:161-171.

194. Liu H, Hu Y, Simpson RW, Dear AE. Glucagon-like peptide-1 attenuates tumour necrosis factor-alpha-mediated induction of plasminogen [corrected] activator inhibitor-1 expression. J Endocrinol. 2008;196:57-65.

195. Hamaguchi E, Takamura T, Shimizu A, Nagai Y. Tumor necrosis factor-alpha and troglitazone regulate plasminogen activator inhibitor type 1 production through extracellular signal-regulated kinase- and nuclear factor-kappaB-dependent pathways in cultured human umbilical vein endothelial cells. J Pharmacol Exp Ther. 2003;307:987-994.

196. Feig DI, Kang DH, Johnson RJ. Uric acid and cardiovascular risk. $N$ Engl J Med. 2008;359:1811-1821

197. Ishizaka N, Ishizaka Y, Toda E, Nagai R, Yamakado M. Association between serum uric acid, metabolic syndrome, and carotid atherosclerosis in Japanese individuals. Arterioscler Thromb Vasc Biol. 2005;25:1038-1044.

198. Gonzalez-Gay MA, Gonzalez-Juanatey C, Vazquez-Rodriguez TR et al. Asymptomatic hyperuricemia and serum uric acid concentration correlate with subclinical atherosclerosis in psoriatic arthritis patients without clinically evident cardiovascular disease. Semin Arthritis Rheum. 2009;39:157-162.

199. Yoo TW, Sung KC, Shin HS. Relationship between serum uric acid concentration and insulin resistance and metabolic syndrome. Circ J. 2005;69:928-933.

200. Lin SD, Tsai DH, Hsu SR. Association between serum uric acid level and components of the metabolic syndrome.J Chin Med Assoc. 2006;69:512-156.

201. Kwon HH, Kwon IH, Choi JW, Youn JI. Cross-sectional study on the correlation of serum uric acid with disease severity in Korean patients with psoriasis. Clin Exp Dermatol. 2011;36:473-478.
202. Isha V K, Lal J, Lal H. C-reactive protein and uric acid levels in patients with psoriasis. Ind J Clin Biochem. 2011;26:309-311.

203. Prasad PV, Bikku B, Kaviarasan PK, Senthilnathan A. A clinical study of psoriatic arthropathy. Indian J Dermatol Venereol Leprol. 2007;73:166-170

204. Pietrzak A, Michalak-Stoma A, Chodorowska G, Szepietowski JC. Lipid disturbances in psoriasis: an update. Mediators Inflamm. 2010;2010:535612.

205. Mallbris L, Granath F, Hamsten A, Ståhle M. Psoriasis is associated with lipid abnormalities at the onset of skin disease. J Am Acad Dermatol. 2006;54:614-621.

206. Frank PG, Marcel YL. Apolipoprotein A-1: structure-function relationship. J Lipid Res. 2000;41:853-872.

207. Wilhelm AJ, Zabalawi M, Owen JS et al. Apolipoprotein A-I modulates regulatory T cells in autoimmune LDLr-/-, ApoA-I-/- mice. J Biol Chem. 2010;285:36158-36169.

208. Tekin NS, Tekin IO, Barut F, Sipahi EY. Accumulation of oxidized low-density lipoprotein in psoriatic skin and changes of plasma lipid levels in psoriatic patients. Mediators Inflamm. 2007;2007:78454.

209. Rocha-Pereira P, Santos-Silva A, Rebelo I, Figueiredo A, Quintanilha A, Teixeira F. Dislipidemia and oxidative stress in mild and in severe psoriasis as a risk for cardiovascular disease. Clinica Chimica Acta. 2001;303:33-39.

210. Piskin S, Gurkok F, Ekuklu G, Senol M. Serum lipid levels in psoriasis. Yonsei Med J. 2003;44:24-26.

211. Vanizor Kural B, Örem A, Çimşit GU, Yandi YE, Calapoglu M. Evaluation of the atherogenic tendency of lipids and lipoprotein content and their relationships with oxidant-antioxidant system in patients with psoriasis. Clinica Chimica Acta. 2003;328:71-82.

212. Hadas E, Bożek A, Jarząb J. Impact of phototherapy on selected lipid profile indices in psoriatic patients allowing for intensification of the disease. Post Dermatol Alergol. 2007;24:215-223.

213. Wharton D, Gharavi N, Navab M, Lee S, Berliner J, Fogelman A, Modlin R. Role of host lipid metabolism and tissue macrophages in psoriasis. J Immunol April. 2011;186:(Meeting Abstract Supplement)147.30.

214. Pepys MB, Hirschfield GM. C-reactive protein: a critical update. J Clin Invest. 2003;101:1805-1812.

215. Ridker PM. C-reactive protein: eighty years from discovery to emergence as a major risk marker for cardiovascular disease. Clin Chem. 2009;55:209-215.

216. Yeh ETH, Palusinski RP. C-reactive protein: the pawn has been promoted to queen. Curr Atheroscler Rep. 2003;5:101-105.

217. Coimbra S, Oliveira H, Reis F et al. C-reactive protein and leucocyte activation in psoriasis vulgaris according to severity and therapy. J Eur Acad Dermatol Venereol. 2010;24:789-796.

218. Kanelleas A, Liapi C, Katoulis A et al. The role of inflammatory markers in assessing disease severity and response to treatment in patients with psoriasis treated with etanercept. Clin Exp Dermatol. 2011 Jul 25. Epub ahead of print.

219. Coimbra S, Oliveira H, Reis F et al. Psoriasis therapy and cardiovascular risk factors: a 12-week follow-up study. $\mathrm{Am}$ J Clin Dermatol. 2010;11:423-432.

220. Yiu KH, Yeung CK, Chan HT et al. Increased arterial stiffness in patients with psoriasis is associated with active systemic inflammation. Br J Dermatol. 2011;164:514-520.

221. Ludwig RJ, Herzog C, Rostock A et al. Psoriasis: a possible risk factor for development of coronary artery calcification. Br J Dermatol. 2007;156:271-276.

Submitted: 30 December, 2011

Accepted after reviews: 20 February, 2012 